\title{
Carbon productivity and flux in the marine ecosystems of the Galapagos Marine Reserve based on cetacean abundances and trophic indices
}

\author{
Productividad y flujo de carbón en los ecosistemas marinos de la Reserva Marina \\ de Galápagos basado en abundancia de cetáceos e índices tróficos
}

\author{
Juan José Alava ${ }^{1,2}$ \\ ${ }^{1}$ School of Resource \& Environmental Management (Environmental Toxicology Research Group); Faculty of Environment, \\ Simon Fraser University, 8888 University Drive, Burnaby, British Columbia V5A 1S6, Canada \\ ${ }^{2}$ Fundación Ecuatoriana para el Estudio de Mamíferos Marinos (FEMM) PO Box 09-01-11905, Guayaquil, Ecuador \\ jalavasa@sfu.ca
}

\begin{abstract}
Resumen.- El rol de los cetáceos en la productividad y flujo de energía en los ecosistemas marinos es escasamente conocido en el Pacifico sureste. Este estudio propone estimar la producción secundaria y terciaria de cinco especies de cetáceos representativos de diferentes ecosistemas marinos de las Galápagos usando cálculos asociados de valores anuales de producción primaria y flujo de carbono, estimaciones de abundancia relativa, biomasa, densidad absoluta y niveles tróficos disponibles en la literatura. De acuerdo a las ecuaciones propuestas para el cálculo de productividad, se obtuvo que el cachalote (Physeter macrocephalus) y la orca carnívorageneralista (Orcinus orca) tuvieron el valor más bajo de producción terciaria al nivel de depredador tope para regiones del océano abierto sin afloramientos, mientras que las ballenas de Bryde (Balaenoptera edeni) y azul (B. musculus) alcanzaron los valores mas altos de producción terciaria (13,7 y 35,4 gC $\mathrm{m}^{-2} \mathrm{yr}^{-1}$, respectivamente) en zonas de afloramientos localizadas al oeste y suroeste de las Islas Galápagos. La producción primaria anual se correlacionó significativamente con las producciones terciarias de ballenas barbadas y odontocetos, usando un nivel de transferencia de energía del 15\%. Cuando se combinó a las especies de cetáceos considerados en este estudio, se encontró una correlación positiva, pero no significativa entre la producción primaria anual y la producción terciaria de cetáceos. Esta relación fue influenciada por los diferentes niveles tróficos en la cadena alimenticia y los valores anuales de productividad primaria de cada uno de los ecosistemas marinos seleccionados. Más investigación es requerida para determinar la abundancia, selección de presas, tasa alimenticias, y tasas de hundimiento de material fecal proveniente de mamíferos marinos en aguas marinas de las Galápagos, así como su función en el flujo vertical de carbón.

Palabras clave: Ballenas de barbas (rorcuales), cachalote, delfín nariz de botella, orca, producción primaria y terciaria, nivel trófico
\end{abstract}

\begin{abstract}
The role of cetaceans in marine ecosystems and food webs is scarcely known in the southeastern Pacific. Estimates of secondary and tertiary (carbon) production and daily food intake were deduced for five species of representative cetaceans for different marine habitats of the Galapagos by using associated calculations of annual primary production and carbon flux, as well as estimations of relative abundance, biomass, absolute density and trophic levels (TL) reported elsewhere. Under these premises, sperm (Physeter macrocephalus) and carnivore-generalist killer whales (Orcinus orca) for open ocean (i.e. no upwelling regions) had the lowest values of tertiary production at the top predator level (0.01-1.01 $\left.\mathrm{gC} \mathrm{m}^{-2} \mathrm{yr}^{-1}\right)$, while Bryde's (Balaenoptera edeni) and blue (B. musculus) whales from upwelling zone located at southwest Galapagos Island yielded the highest cetacean production (13.7 and 35.4 $\mathrm{gC} \mathrm{m}^{-2} \mathrm{yr}^{-1}$, respectively). Significant positive correlations at a $15 \%$ of efficiency transfer were found between the estimated annual primary production and tertiary production of baleen whales, and between annual primary production and tertiary production of toothed cetaceans. When both groups of cetaceans were combined a no significant correlation was observed between cetacean production and annual primary productivity. This outcome was influenced by their different trophic positions in the food chain and different scenarios values of annual primary productivity of the marine ecosystems selected. More research is needed to determine abundance, prey selection, feeding rates, and fecal matter sinking rates from marine mammals in Galapagos waters, as well as their function in the vertical carbon flux.
\end{abstract}

Key words: Baleen whales, sperm whale, bottlenose dolphin, killer whale, primary and tertiary production, trophic level 


\section{Introduction}

Marine mammals provide useful information on the ecological structure of the marine ecosystem to which they inhabit and reflect the marine trophic spectrum involving primary production, consumers, top predators, microbial loop and sedimentation (Joiris 2000). Marine mammals are consumers at most trophic levels feeding on benthic dweller organisms, zooplankton, fish and even other marine mammals (Bowen 1997). The predation role performed by cetaceans and pinnipeds, for example, is crucial to control the zooplankton abundance and fish population in some areas of the worldwide ocean, mainly in Antarctic and Artic marine zones (Lalli \& Parsons 1997). Moreover, some species of whales are keystone elements in balancing marine food webs. For example, the depletion of Antarctic baleen whales allowed more of the euphasiid biomass ( 150 million ton) to other competing species such as remaining whales, seals, seabirds and fish, and therefore increased the populations of Antarctic seals and birds by about a factor of at least three (Laws 1985, Lalli \& Parsons 1997).

Some species of marine mammals are critical apex predators (e.g. killer whales), which can affect a system under top-down control, including the diminishing of plant populations (i.e. kelp forests) at the base of the trophic chain (Estes et al. 1998). Marine mammals tend to occupy specific habitats in the ocean with most species found exclusively or primarily in waters with a particular depth and specific ranges of temperature and oceanographic conditions. Other species are migrants and travel between regions where seasonal oceanic conditions promote high nutrient budgets in order to exploit this richness (Jefferson et al. 1993). Then, a strong relationship between oceanic physical factors such as the Pacific subarctic gyres and abundance and distributions of marine mammals has been documented (Springer et al. 1999).

The flow of energy through the cetaceans and pinnipeds, as biotic components of marine ecosystems, has been viewed as evidence of their ecological significance and consumption of prey (Bowen 1997). In marine mammals, both rates of energy and biomass ingestion are based on body mass, and have been described by using allometric equations elsewhere (Innes et al. 1987, Joiris 1992, 2000, Joiris \& Tahon 1992). Joiris (2000) has pointed out that quality and quantity of the food availability from primary production to microbial loop and sedimentation can be assessed from the quantitative analysis of the distribution at sea of marine mammals and seabirds. In the marine biosphere, the main process controlling carbon flux is the biological pump in which organic matter and dead organisms that come from the upper water layers sink to the bottom of the ocean, and therefore, the carbon is accumulated there for a period of time until the current system of deep mass waters deliver it to the atmosphere (Legendre \& Rivkin 2002).

The diversity of marine mammals in the Galapagos Islands $\left(0.5^{\circ} \mathrm{S}-90.5^{\circ} \mathrm{W}\right)$ is the result of three main factors: a) the existence of oceanographic habitats feasible for the establishment of typical communities from the tropics and equatorial water masses; $b$ ) the existence of physical habitats available to both coastal and pelagic species; and c) a high biological productivity (primary productivity) because of the upwelling (Palacios et al. 1996 ${ }^{1}$; Palacios 2003). Similarly, there are three main aquatic habitats in the Galapagos (Merlen 1995): 1) coastal waters; 2) shallow continental shelf region between the central and austral islands; and 3) oceanic deep waters (2000 to 3000 $\mathrm{m}$ ), which are located around the perimeter of the islands, especially southward, westward and northward, including upwelling zones. The geographical and oceanographic characteristics around the Galapagos Islands provide extraordinary environmental conditions, allowing the presence of a significant biodiversity of both resident and migratory cetacean species (Palacios \& Salazar 2002), including (Physeter macrocephalus) and killer whales (O. orca) (Merlen 1995, 1999, Palacios 1999a, b). Communities of small delphinids such as pan-tropical spotted (Stenella attenuata) and spinner dolphins (S. longirostris) are also found in areas of strong watercolumn stratification. Nearshore and upwelling areas are the habitat of the short-beaked common dolphin (Delphinus delphis), bottlenose-dolphin (Tursiops truncatus), Risso's dolphin (Grampus griseus), and shortfinned pilot whales (Globicephala macrorhynchus), as well as baleen whales such as Bryde's whales (Balaenoptera edeni) (Palacios 2003). The western part of the Galapagos Islands generally has a higher abundance of cetaceans due to the high primary productivity and upwelling systems (Merlen 1995, Alava 2002, Palacios 2003).

There has been little attention regarding the study of marine mammal biomass production and its role on energy flow in the southeastern tropical Pacific Ocean region. The aim of this study is focused on the use of estimates of primary productivity, carbon flux and abundance of cetacean to infer tertiary production of cetaceans and their

${ }^{1}$ Palacios D, T Gerrodette \& D Day. 1996. Marine mammal diversity off the Galapagos Islands, Ecuador. Resúmenes VII Reunión de Trabajo de Especialistas en Mamíferos Acuáticos de América del Sur y $1^{\text {er }}$ Congreso de la Sociedad Latinoamericana de Especialistas en Mamíferos Acuáticos, 2225 octubre, Viña del Mar, Chile. p. 72. 
trophic role in marine ecosystems of the Galapagos Marine Reserve (GMR). To accomplish this, several bioecological parameters were associated and connected by theoretical calculations to deduct primary production, flux of carbon and cetacean production. Using these approaches, data on chlorophyll $a$, cetacean density, energy consumption budgets by cetacean species, trophic position and trends on primary production versus tertiary production is presented.

\section{Material and methods}

\section{1- Baseline information}

\section{Trophic levels in cetaceans}

For this study the trophic levels for different cetacean species reported by Pauly et al. (1998) and Okey et al. (2004) were used (Table 1, Fig. 1). Diet and feeding behaviors establish the position of marine animals into trophic webs, and determine their ecological function as either predators or preys (Pauly et al. 1998). The trophic levels of marine mammals range from 3.2-3.4 in baleen whales to 3.8-4.4 in most species of toothed cetaceans and pinnipeds, and to 4.5-4.6 in killer whales. For instance, the trophic level for toothed cetaceans inhabiting rocky reef areas of the Galapagos has been estimated at about 4.4 by Okey et al. (2004), which are within the range of those reported by Pauly et al. (2004).

\section{Cetacean species and ecological parameters}

The rationale to select candidate species of cetaceans was based on the following criteria: a) species officially identified as a marine mammal commonly reported within the boundaries and marine area $\left(138,000 \mathrm{~km}^{2}\right)$ of the GMR (Merlen 1995); and b) species fairly recorded during scientific-oceanographic expeditions around $3^{\circ} \mathrm{N}-4^{\circ} \mathrm{S}$ and $87^{\circ}-94^{\circ} \mathrm{W}$, including the waters of the GMR, from 1973 to 2000 (Palacios \& Salazar 2002, Alava 2002, Palacios 2003). Detailed maps on the distribution of marine mammals around waters of the GMR are available elsewhere (Merlen 1995, Palacios \& Salazar 2002). Briefly, a map of marine mammal abundance and distribution, including cetacean species, in waters around the Galapagos is depicted in Fig. 2.

Pauly et al. (1998) listed a diverse range of diet items for baleen whales. According to this information, it is noted that all the baleen whales (Balaenopteridae) such as Bryde's (B. edeni), blue and humpback (Megaptera novaeangliae) whales are planktivorous animals grazing

Table 1

Selected species of cetaceans recorded in marine waters off Galapagos Islands, including their diet composition, estimates of relative abundance, absolute density, biomass and daily intake. Diet (preys categories) and trophic levels (TLs) were obtained from Pauly et al. (1998); mean masses were calculated from Trites \& Pauly (1998)

Especies de cetáceos escogidos para este estudio y registrados en aguas marinas de las Islas Galápagos, incluyendo la composición de sus dietas y las estimaciones de sus abundancias relativas, densidad absoluta, biomasa e ingestión diaria. La dieta (categorías de presas) y los niveles tróficos fueron obtenidos a partir de Pauly et al. (1998); las masas promedios fueron calculados a partir de Trites \& Pauly (1998)

\begin{tabular}{|c|c|c|c|c|c|c|c|}
\hline Family/species & Diet composition & TL & $\begin{array}{l}\text { Abundance } \\
\text { (individuals) }^{\mathrm{a}}\end{array}$ & $\begin{array}{c}\text { Density }(N) \\
\text { animals km } \\
\text {-2 }\end{array}$ & $\begin{array}{l}\text { Mean mass } \\
\quad(\mathrm{kg})\end{array}$ & $\begin{array}{c}\text { Biomass ( } W \text { ) } \\
\text { (abun. x mass) }\end{array}$ & $\begin{array}{c}\text { Daily intake }\left(\mathrm{kg} \mathrm{km}^{-2}\right) \\
I=0.191 W^{0.723} \mathrm{~N}\end{array}$ \\
\hline \multicolumn{8}{|l|}{ Balaenopteridae } \\
\hline Balaenoptera musculus & $\mathrm{LZ}$ & 3.2 & 36 & 0.0003 & 102,737 & $3,698,514$ & 3 \\
\hline Balaenoptera edeni & LZ, SS,SP, MP,MF & 3.7 & 500 & 0.0040 & 16,143 & $8,071,500$ & 75 \\
\hline \multicolumn{8}{|l|}{ Physiteridae } \\
\hline Physeter macrocephalus & BI, SS, LS, SP, MP, MF & 4.4 & 177 & 0.0014 & 18,519 & $3,277,775$ & 13 \\
\hline \multicolumn{8}{|l|}{ Delphinidae } \\
\hline Orcinus orca & SS, LS, SP, MF, HV, EF & 4.5 & 156 & 0.0012 & 2,281 & 355,758 & 2 \\
\hline Tursiops truncatus & SS, LS, SP, MF & 4.2 & 12,000 & 0.0920 & 188 & $2,250,000$ & 688 \\
\hline
\end{tabular}

$\mathrm{BI}=$ benthic invertebrates (bivalves, gastropods, octopus, echinoderms and crustaceans); LZ= large zooplankton (small crustaceans, especially euphasiids such as Euphausia superba, krill, in Antarctic waters); SS= small squids (e.g.Family: Gonatidae); LS= large squids (e.g. Family: Onychoteuthidae); SP= small pelagic fishes (Consisting of clupeoids; small scombroids); MP= mesopelagics fishes (Family: Myctophidae and other groups of the Deep Scattering Layer); MF= miscellaneous fishes (a diverse group consisting mainly of demersal round fish such as gadoids and percifoms, but also including anadromous fish); HV= higher vertebrates (marine mammals, seabirds, plus occasional sea turtles). The category EF (elasmobranches fish) was created here since Galapagos orcas have been documented to consume sharks and rays (Fertl et al. 1996, Merlen 1999, Sorisio et al. 2006). TL = trophic level

a Abundance of cetaceans in the Galapagos was obtained from Palacios \& Salazar (2002) 


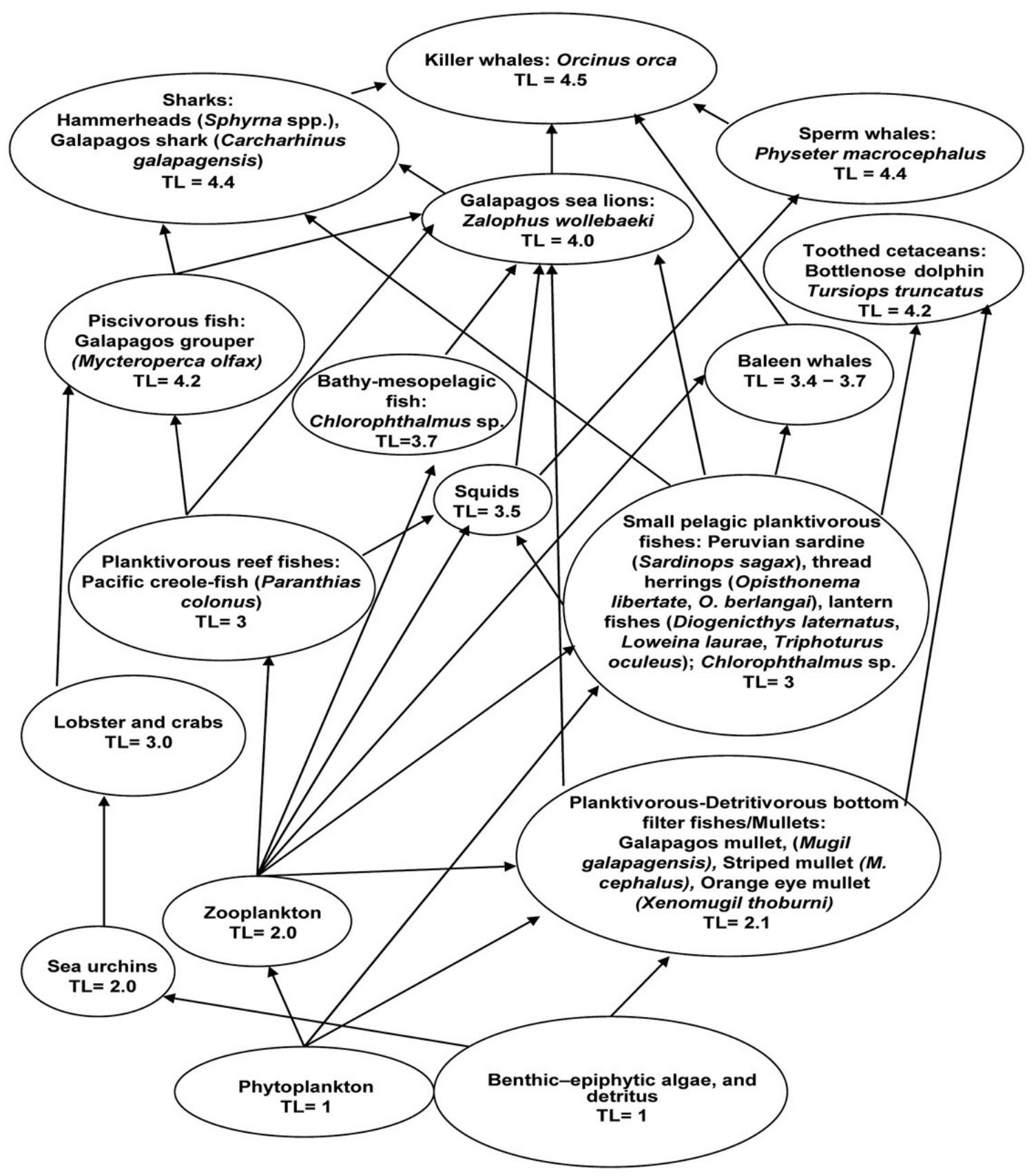

Figure 1

A simplified Galapagos marine food web showing the trophic positions of marine mammals, including cetaceans, and interactions with lower trophic levels (TLs), including their diet items. The construction of this food web and trophic levels of organisms (except for cetaceans) was based on Okey et al. (2004). For squids, the TL was assumed to be the same as for octopus. TLs for cetaceans were obtained from Pauly et al. (1998)

Red trófica marina de las Galápagos simplificada mostrando los niveles tróficos de mamíferos marinos, que incluye cetáceos, y las interacciones con niveles tróficos inferiores, incluyendo sus presas parte de la dieta. La construcción de esta red alimenticia y los posiciones tróficas de los organismos, excepto para cetáceos, fue basada en Okey et al. (2004). En el caso de los calamares, se usó el nivel trófico para pulpo. Los niveles tróficos para cetáceos fueron obtenidos de Pauly et al. (1998) 


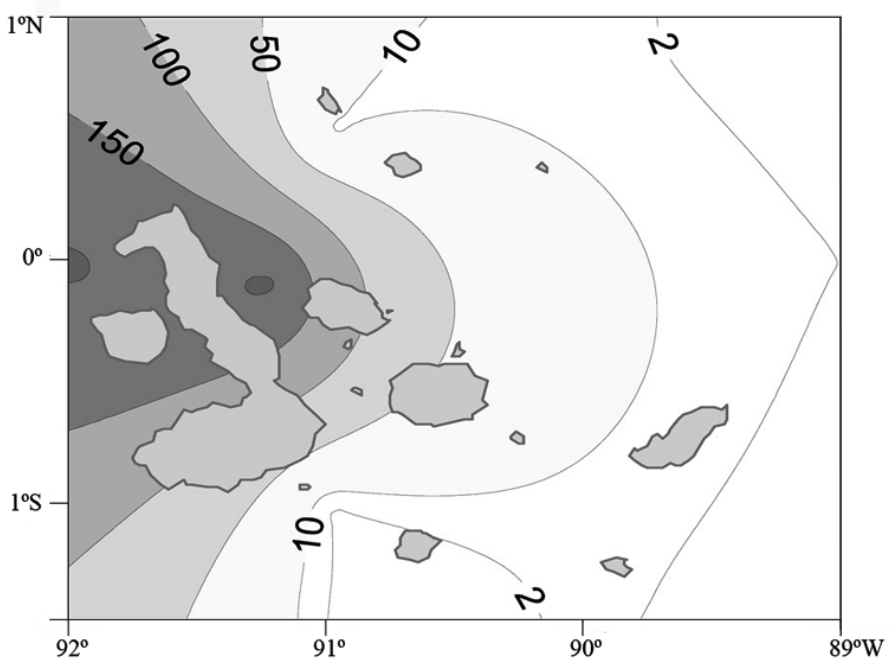

Figure 2

Relative abundance and distribution of marine mammals in waters of Galapagos Islands (GMR). Values on isoclines indicate abundance of cetaceans (number of individuals) around the islands. The cetacean abundance is higher in highly productiveupwelling areas located at western Galapagos Islands (dark, grey regions), whereas it decreases at eastern side (white region) of the islands (Oceanographic-Insular Cruise of the Ecuadorian NAVY-INOCAR, August 2000; adapted from Alava (2002)

Abundancia relativa y distribución de mamíferos marinos en aguas de las Islas Galápagos (Reserva Marina Galápagos-RMG). Los valores de las isoclinas señalan la abundancia de cetáceos (numero de animales) alrededor de las Galápagos. La abundancia de cetáceos es mayor en zonas de surgencias altamente productivas localizadas al oeste de las Islas Galápagos (regiones grises oscuras), mientras que la misma decrece en la parte este (región blanca) de las islas (Crucero Oceanográfico Insular de la Armada-INOCAR del Ecuador, agosto de 2000; adaptado de Alava (2002)

mainly on krill (Euphausia spp., Nyctiphanes sp.) biomass and other meso-zooplanktonic crustacean, as well as schools of small pelagic fishes, existing either in Antarctic or in Galapagos waters. Only the Bryde's and blue whales were considered for calculations of large cetacean productivity since these cetaceans are more regularly observed in the Galapagos.

Bryde's whales are the most commonly sighted baleen whale in the GMR, where this cetacean is strongly associated to the major nucleus of upwelling coupled with the Cromwell current (Palacios \& Salazar 2002). A total of 316 sightings of this species, with an average size per group of 1.6 individuals, were recorded during oceanographic cruises from 1973 to 2000 (Palacios 2003, Palacios \& Salazar 2002). Based on the data provided by these authors, this indicates a relative abundance of about 500 Bryde's whales in Galapagos waters (Table 1). Dividing the documented number of Bryde's whales reported above by the total area of the GMR (here rounded to $\approx 130,000 \mathrm{~km}^{2}$ for calculations), an absolute density of 0.004 whales $\mathrm{km}^{-2}$ is yielded.

Although the blue whale is less abundant around
Galapagos waters compared to Bryde's whales (Merlen 1995, Palacios \& Salazar 2002), it was included given that a relatively high numbers of sightings and strandings of south-east Pacific blue whales have recently been reported, despite its population status is still unclear (Branch et al. 2007). Blue whales are predominantly distributed to the west and southwest of the Galapagos, where nutrient-enriched surface waters with high planktonic biomass (i.e. upwelling) occur (Palacios 1999a). From 1978 to 1995, about 17 groups of blue whales with a total of 36 individuals (average size per group $=2.11$ ) were recorded in Galapagos waters, where about $22 \%$ of the sightings were groups containing three or more whales (Palacios 1999a, b, Branch et al. 2007). The sighting rate for this species around the Galapagos Islands was 0.25 groups per $1000 \mathrm{~km}$ (Palacios 1999b, Branch et al. 2007). Thus, an absolute density of 0.0003 whales $\mathrm{km}^{-2}$ is estimated for the GMR (36 individuals per $130,000 \mathrm{~km}^{2}$ ) (Table 1).

Sperm whales were the largest toothed cetaceans frequently observed around Galapagos waters, where an important, local population of females and immatures was 
likely to occur during the late 1980s, with an estimated population of about $2000-<4000$ individuals (see Fig. 4.5 in Whitehead 2003). The sperm whales absolute density for Galapagos waters is not available, but the density reported for the eastern tropical Pacific Ocean (1.36 whales per $1000 \mathrm{~km}^{2}$ ) by Whitehead (2002) was adopted, and then the population was calculated for the Galapagos Marine Reserve [(1.36 whales per 1000 $\left.\mathrm{km}^{2}\right)^{*}\left(130 \times 10^{3} \mathrm{~km}^{2}\right)=177$ whales, Table 1$]$. The sperm whale is a superior candidate to estimate tertiary production in the oceanic zone, predating on several types of large squids such as Architeuthis, Histioteuthis, Ancistrocheirus, Octopoteuthis, Pholidoteuthis, Liocranchia, Discoteuthis, and Morotherius (Pauly et al. 1998, Smith \& Whitehead 2002, Flinn et al. 2002) (Table 1). These whales reach a trophic level of 4.4 in the marine food web.

The bottlenose dolphin was included as this species is fairly abundant and commonly observed year round in the Galapagos, mainly in coastal areas (Merlen 1995, Palacios \& Salazar 2002). This species has been identified as a key predator among the small toothed cetaceans in the Galapagos marine food webs (Okey et al. 2004; Fig. 1). In the GMR, the bottlenose dolphin has been attributed to belong to the offshore or oceanic ecotype. Its average size group is estimated at about 33 dolphins. Based on the 366 sightings of this species recorded from 1973 to 2000 (Palacios \& Salazar 2002, Palacios 2003), a relative abundance of 12,000 individuals, with an absolute density of 0.1 dolphins $\mathrm{km}^{-2}$, is estimated for the GMR.

Killer whales are cosmopolitan cetaceans and they predate on several categories of animals including other marine mammals (Table 1). In the Galapagos Islands, this species is categorized as carnivore-generalist and eats on teleosts, chondrichthyes, turtles, cetaceans and otariids, as evidenced by a significant number of field observations ( $n=135$ ) reported by Merlen (1999). The average size per group for killer whales ranged from 3.1 to 5.1 individuals (Merlen 1999). Using a mean of 4.1 individuals calculated from these two averages and the 38 observations listed by Palacios (2003) for the period 1973-2000, a relative abundance of at least 156 killer whales with a density of 0.001 individuals $\mathrm{km}^{-2}$ is assumed to exist in waters of the GMR (Table 1).

\section{2-Calculations of productivity}

\section{Primary and tertiary production}

The abundance of marine mammals has been found to be relatively higher at the west part $\left(92-91^{\circ} \mathrm{W}\right)$ of the GMR

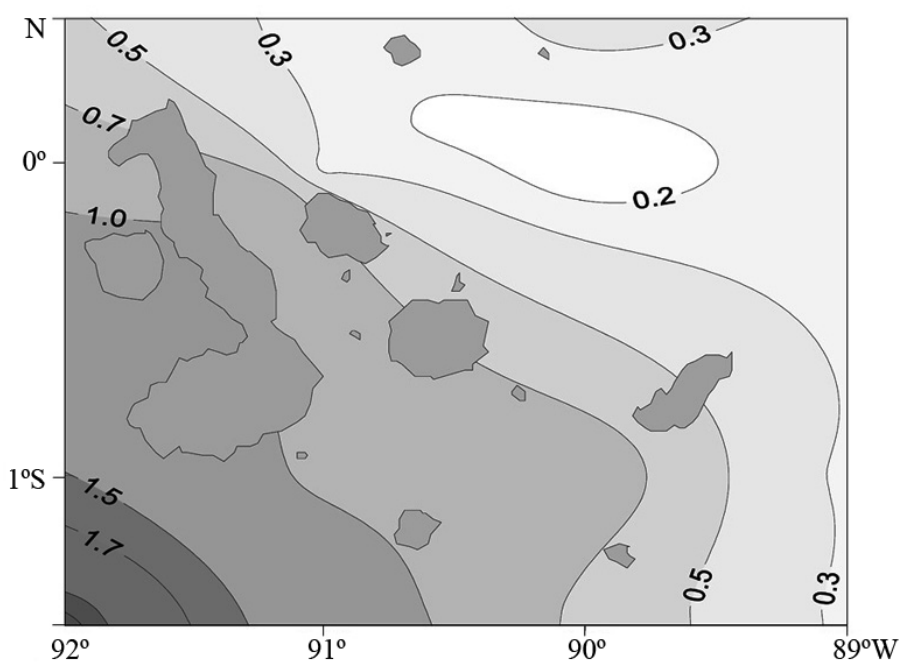

Figure 3

Concentration and distribution of chlorophyll $a\left(\mathrm{mg} \mathrm{m}^{-3}\right)$ in the marine area of Galapagos Islands. Numbers on isoclines indicate concentration of primary production around the islands. Higher values of primary productivity are present to the west and southwest (dark, grey regions) of the Galapagos Marine Reserve (Oceanographic-Insular Cruise of the Ecuadorian NAVY-INOCAR, August 2000; adapted from Alava (2002)

Concentración y distribución de clorofila $a\left(\mathrm{mg} \mathrm{m}^{-3}\right)$ en el área marina de las Islas Galápagos. Los números de las isoclinas señalan la producción primaria alrededor de las islas. Los valores altos de productividad primaria están presentes al oeste y sureste (regiones grises oscuras) de la Reserva Marina Galápagos (Crucero Oceanográfico Insular de la Armada-INOCAR del Ecuador, agosto de 2000; adaptado de Alava (2002) 
(Fig. 2; Alava 2002), where elevated concentrations of surface chlorophyll $a$ have also been observed (Fig. 3; Alava 2002). This region of high primary production is associated with the Cromwell upwelling and another flow southeastern Galapagos $\left(90^{\circ} \mathrm{W}\right)$ linked with the Humboldt Stream (Torres \& Tapia 2002).

To develop the estimates of annual primary production in this study for the coastal-marine habitats mentioned above, the chlorophyll concentration for the euphotic (42 $\left.\mathrm{mg} \mathrm{m}^{-3}\right)$ and surface zone $\left(0.65 \mathrm{mg} \mathrm{m}^{-3}\right)$ coupled with the recent primary production estimate reported by Pennington et al. (2006) were used as constant parameters to extrapolate theoretical values of annual primary production in units of $\mathrm{C} \mathrm{m}^{-2} \mathrm{yr}^{-1}$. Based on this reasoning, the average chlorophyll concentrations calculated from the ranges obtained by Tapia \& Torres (2002) and Barun et al. (2005) were divided to $42 \mathrm{mg} \mathrm{m}^{-3}$ or $0.65 \mathrm{mg} \mathrm{m}^{-3}$ and then multiplied by $979 \mathrm{gC} \mathrm{m}^{-2} \mathrm{yr}^{-1}$ (see Table 2). Additionally, for the Equatorial upwelling region of the Galapagos, the actual value of primary production (979 $\mathrm{gC} \mathrm{m}^{-2} \mathrm{yr}^{-1}$ ) was also used to yield baleen and sperm whales production since concentrations of primary production at this region have shown to be two times greater than other productive regions of the eastern Pacific Ocean (Pennington et al. 2006). The conversion factor equation was stated as: [average observed chlorophyll $a\left(\mathrm{mg} \mathrm{m}^{-3}\right)$ high (42) or low (0.65) chlorophyll $a\left(\mathrm{mg} \mathrm{m}^{-3}\right) \times 979 \mathrm{gC}$ $\left.\mathrm{m}^{-2} \mathrm{yr}^{-1}\right)$.

To explain the transfer of energy within the marine system, marine zones including coastal and open ocean areas, as well as upwelling located western Galapagos Islands were used. Calculations of several scenarios of primary productivity for coastal, open ocean and upwelling zones using the conversion factor equation are depicted as footnotes below Table 2. The five cetaceans listed in Table 1 were selected for the estimation of tertiary production under the premise involving different scenarios of annual primary productivity (i.e. low and high primary production) for the marine zones in the Galapagos Islands (Table 2): Bryde's and blue whales for upwelling zones, which include scenarios I (35.5 $\mathrm{C} \mathrm{m}^{-2} \mathrm{yr}^{-1}$ ) and II (2297 $\mathrm{C} \mathrm{m}^{-2} \mathrm{yr}^{-1}$ ), and Equatorial upwelling (979 $\mathrm{gC} \mathrm{m}^{-2}$ $\left.\mathrm{yr}^{-1}\right)$; the bottlenose dolphin, for coastal areas, which include scenarios I (67.1 $\left.\mathrm{gC} \mathrm{m}^{-2} \mathrm{yr}^{-1}\right)$ and II (4338 $\mathrm{gC} \mathrm{m}^{-2}$

Table 2

Estimates of annual primary productivity $\left(\mathrm{gC} \mathrm{m}^{-2} \mathrm{yr}^{-1}\right)$, tertiary (cetacean) production $\left(\mathrm{gC}^{-2} \mathrm{yr}^{-1}\right)$ and biomass $\left(\mathrm{kg}\right.$ per $\left.100 \mathrm{~km}^{2}\right)$ of five species of marine mammals in selected habitats of the Galapagos

Estimaciones de la productividad primaria anual $\left(\mathrm{gC} \mathrm{m}^{-2} \mathrm{yr}^{-1}\right)$, productividad terciaria (cetáceos) y biomasa ( $\mathrm{kg}$ por $\left.100 \mathrm{~km}^{2}\right)$ de cinco especies de mamíferos marinos en hábitats seleccionados de las Galápagos

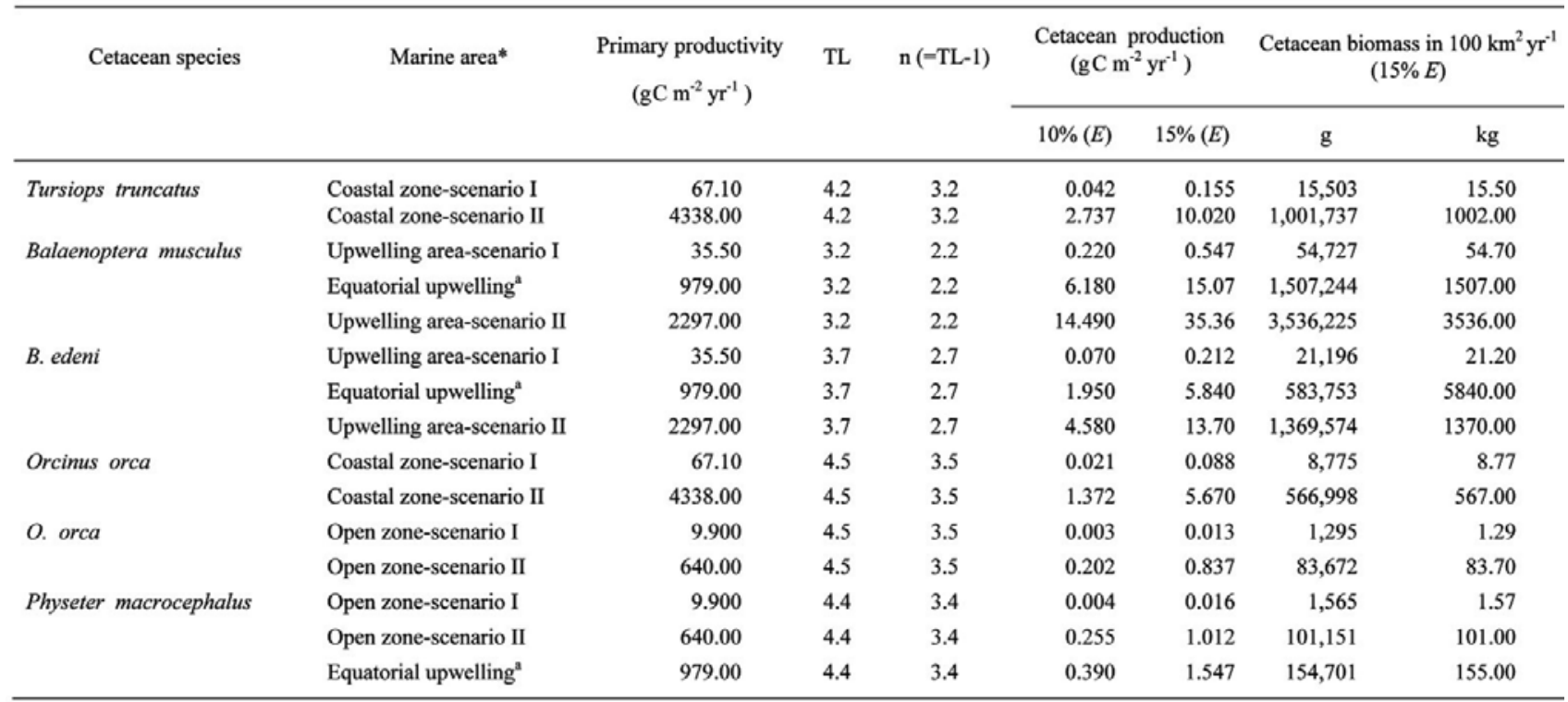

*The minimum and maximum values of chlorophyll $a$ for coastal waters (i.e. Academy Bay, Santa Cruz) and for upwelling zones (i.e. southwest off Galapagos) were $2.58-3.18$ mg m ${ }^{-3}$ and $0.87-2.18 \mathrm{mg} \mathrm{m}^{-3}$, respectively (Torres \& Tapia 2002). For oceanic habitat, several values determined between the $92^{\circ} \mathrm{W}$ and $2^{\circ}-3^{\circ} \mathrm{S}\left(0.24-0.98 \mathrm{mg} \mathrm{m}^{-3}\right)$, and between the $89^{\circ} \mathrm{W}$ and $2^{\circ}-3^{\circ} \mathrm{S}\left(0.38-0.10 \mathrm{mg} \mathrm{m}^{-3}\right)$ have been recorded (Braun et al. 2005). Coastal zone-scenario I $=\left(2.88 \mathrm{mg} \mathrm{m}^{-3}+42 \mathrm{mg} \mathrm{m}^{-3}\right)^{*} 979 \mathrm{~g} \mathrm{C} \mathrm{m}^{-2} \mathrm{yr}^{-1} ;$ Coastal zone-scenario II $=\left(2.88 \mathrm{mg} \mathrm{m}^{-3}+\right.$

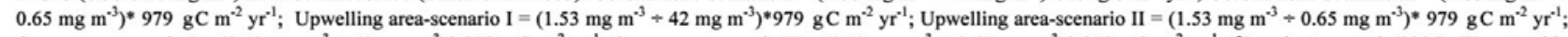
Open zone-scenario $\mathrm{I}=\left(0.43 \mathrm{mg} \mathrm{m}^{-3} \div 42 \mathrm{mg} \mathrm{m}^{-3}\right)^{*} 979 \mathrm{gC} \mathrm{m}^{-2} \mathrm{yr}^{-1}$; Open zone-scenario II $=\left(0.43 \mathrm{mg} \mathrm{m}^{-3} \div 0.65 \mathrm{mg} \mathrm{m}^{-3}\right)^{*} 979 \mathrm{gC} \mathrm{m}^{-2} \mathrm{yr}^{-1}$; ${ }^{2} \mathrm{Pennington}$ et al. $(2006)$; $\mathrm{TL}=$ trophic level; $E=$ transfer efficiency. 
$\left.\mathrm{yr}^{-1}\right)$; the killer whale both for open oceanic zones, including scenario I with low productivity $\left(9.9 \mathrm{gC} \mathrm{m}^{-2} \mathrm{yr}^{-1}\right)$ and scenario II with high productivity $\left(640 \mathrm{gC} \mathrm{m}^{-2} \mathrm{yr}^{-1}\right)$ and for coastal areas, including scenarios I $\left(67.1 \mathrm{gC} \mathrm{m}^{-2}\right.$ $\left.\mathrm{yr}^{-1}\right)$ and II (4338 $\left.\mathrm{gC} \mathrm{m}^{-2} \mathrm{yr}^{-1}\right)$; and the sperm whale for open ocean with scenario I $\left(9.9 \mathrm{gC} \mathrm{m}^{-2} \mathrm{yr}^{-1}\right)$ and scenario II $\left(640 \mathrm{gC} \mathrm{m}^{-2} \mathrm{yr}^{-1}\right)$, as well as Equatorial upwelling (979 $\left.\mathrm{gC} \mathrm{m}^{-2} \mathrm{yr}^{-1}\right)$.

To predict the production $\left(P_{(n+1)}\right)$ in a given marine mammal trophic level, the following equation was used (Lalli \& Parsons 1997):

$$
P_{(n+1)}=P_{1} E^{n}
$$

where, $P_{1}$ is the annual primary production $\left(\mathrm{gC} \mathrm{m}^{-2} \mathrm{yr}^{-1}\right)$, $E$ the ecological efficiency $(=10 \%=0.1)$, and $n$ the number of energy transfers between trophic levels (= number of trophic levels minus 1 ). In addition, it is necessary to know how much energy is transferred between trophic levels. This energy is called ecological efficiency $(E)$, and it is defined as the amount of energy extracted from a given trophic level divided by the energy supplied to that trophic level (Lalli \& Parsons 1997). However, ecological efficiency is difficult to measure; therefore, the transfer efficiency (Lalli \& Parsons 1997):

$$
E_{T}=P_{t} / P_{t-1}
$$

where $P_{\mathrm{t}}$ is the annual production at trophic level $t$; and $P_{\mathrm{t}-1}$ the annual production in the preceding trophic level $(t-1)$. This approach is less difficult to measure and generally the value of energy calculated for transfer efficiency estimations. Values for transfer efficiency have been estimated in the marine ecosystem with the transfer from phytoplankton to herbivores at about $20 \%$ and the transfer to higher trophic levels about 15 and 10\% (Pauly \& Christensen 1995, Young \& Phillips 2002). These authors suggest that $10 \%$ is a more conservative value and represents a minimum estimate for trophic transfer rates. For this study, both 0.10 and 0.15 were used in the calculations to account for uncertainty.

\section{Energy flow and biomass consumption}

Energy and biomass consumption was calculated applying the allometric equation used by Joiris (1992) and Joiris \& Tahon (1992), which represents daily food intake from density data (numbers per $\mathrm{km}^{2}$ ), is expressed as follows:

$$
I=0.191 W^{0.723} \mathrm{~N}
$$

where, $I$ is the daily ingestion in $\mathrm{kg}$ fresh weight (fw)/ $\mathrm{km}^{2}, W$ is the average individual biomass in $\mathrm{kg}$ and $N$ the density in numbers per $\mathrm{km}^{2}$. The allometric equation was applied for the five cetacean species using their population abundance and absolute densities (Table 1), as well as their estimated biomass resulting from the product between the estimates of their abundance and the average mass, calculated from the mean masses for males and females of each species (Table 1) reported by Trites \& Pauly (1998).

\section{Sinking rates of fecal matter}

Smith (1992) found that small upper and lower squids beaks (LRL $=4.0 \mathrm{~mm}$ ) defecated by sperm whales sink at a rate of $2.16 \mathrm{~m} \mathrm{~min}^{-1}$ and $1.92 \mathrm{~m} \mathrm{~min}^{-1}$, respectively, and the largest upper and lower squids beaks sink at rates very close to $3.00 \mathrm{~m} \mathrm{~min}^{-1}$. Assuming that sinking rates for fecal matter excreted by marine mammals (e.g. baleen whales or sperm whales) is also a function of size such as Bruland \& Silver (1981) considered it to salp fecal pellets, the sinking rates of fecal matter from whales could sink faster (e.g. blue and sperm whales). Defecation by blue whale was frequently recorded around the south and southwest upwelling zones off Galapagos (Palacios 1999b). Unfortunately, data on fecal matter sinking rates for blue whales has not been documented. Because of the importance of the influx of carbon through deposition rates of organic carbon from organism, an exploration of the role of fecal matter coming from cetaceans of the Galapagos is also analyzed here by focusing on the sperm whale biomass by using the data reported elsewhere (Smith 1992, Smith \& Whitehead 2000).

\section{Results}

According to the equation (1), the maximum tertiary production, with a $15 \%$ of efficiency transfer, yield by blue and Bryde's whales, bottlenose dolphin, and killer whales are 35, 14, 10 and $5.67 \mathrm{gC} \mathrm{m}^{2} \mathrm{yr}^{-1}$, respectively (Table 2). In other words, the amount of carbon fixed per $100 \mathrm{~km}^{2}$ annually around Galapagos Island waters is about 3.54 ton $(\approx 3536 \mathrm{~kg})$ for a blue whale and about 1.3 ton $(\approx 1370 \mathrm{~kg}$ ) for a Bryde's whale. These two cetaceans can be used as biological indicators of tertiary production in upwelling areas in the Galapagos (Fig. 3) since these baleen whales contribute with the highest values of tertiary production (Fig. 4). Interesting, bottlenose dolphins can yield a maximum of 1 ton per $100 \mathrm{~km}^{2}$ annually in coastal areas, where high levels of chlorophyll can be occasionally detected (Torres \& Tapia 2002). This suggests its use as key indicator of coastal production at apex levels. In the open ocean, tertiary production tends to be less than in coastal areas if both areas have the same top predator (O. orca). For instance, whereas killer whales yield between 0.1 and $6 \mathrm{gC} \mathrm{m}^{-2} \mathrm{yr}^{-1}$ in coastal waters, in the open ocean (i. e. attacking a sperm whale) these mammals yield a maximum of $1 \mathrm{gC} \mathrm{m}^{-2} \mathrm{yr}^{-1}$. This represents one of 


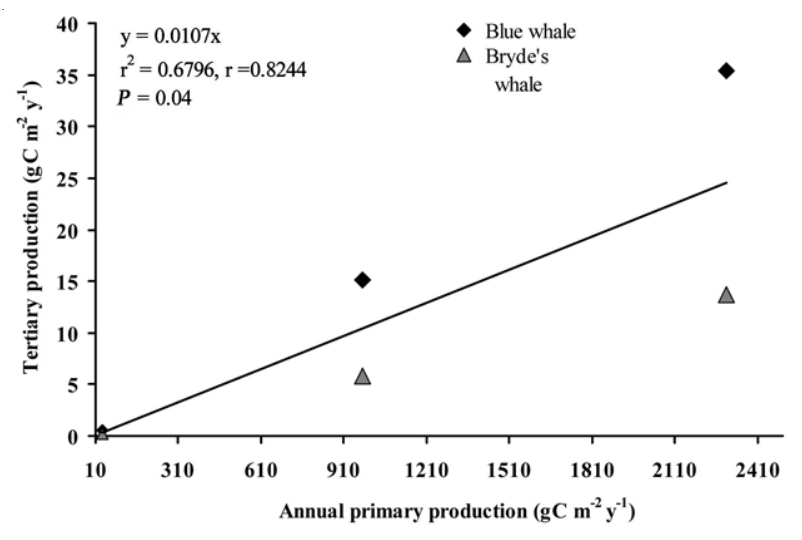

Figure 4

Linear regression model between the estimated annual primary productivity and tertiary production of Mysticetes for different marine habitats. A significant relationship was found between the two variables

Modelo de regresión lineal mostrando las estimaciones de productividad primaria anual y producción terciaria de

Mysticetos para los diferentes escenarios (hábitats marinos). Se determinó una asociación significativa entre las dos variables the lowest values of carbon production in a tertiary production level with a transfer efficiency of 15\% (Table 2). Both killer whales and bottlenose dolphin required high amounts of primary production in coastal zones (Table 2, Fig. 5).

The tertiary production for sperm whales shows the lowest values ranging from 0.02 to $1.55 \mathrm{gC} \mathrm{m}^{-2} \mathrm{yr}^{-1}$ (Table 2, Fig. 5), although sperm whales have a high trophic level (TL=4.4). This can be explained by the fact that these toothed whales are inhabitants of oceanic habitats where low concentrations of chlorophyll are detected. Therefore, the maximum biomass in the Equatorial upwelling for this species is $155 \mathrm{~kg}$ per $100 \mathrm{~km}^{2} \mathrm{yr}^{-1}$. These cetaceans rely on large squids found in deep oceanic waters, thus calculations of tertiary production in these marine mammals must consider other foraging factors rather than only primary production.

At a $15 \%$ level of transfer efficiency, a non significant positive correlation was found between the annual primary production and cetacean production $(r=0.49 ; P>0.05)$. When using a $10 \%$ of transfer efficiency, a weak non significant correlation was found $(r=0.39 ; P=0.15$, data no shown). When exploring data by group of cetaceans

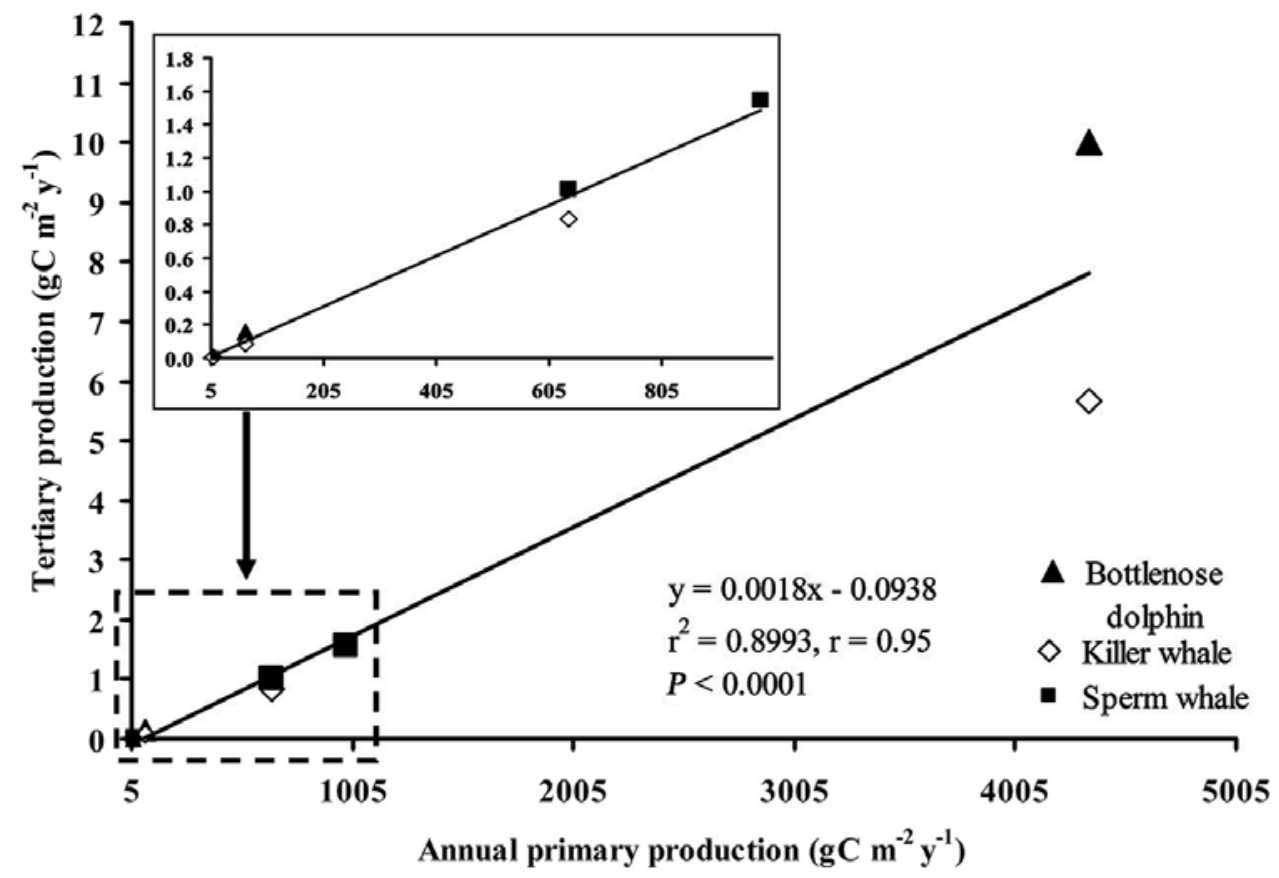

Figure 5

Linear regression model between the estimated annual primary productivity and tertiary production of Odontocetes for different marine habitats. A significant relationship was found between the two variables

Modelo de regresión linear mostrando de las estimaciones de productividad primaria anual y producción terciaria de Odontocetos para los diferentes escenarios (hábitats marinos). Se determinó una asociación significativa entre las dos variables 
(suborders Mysticetes and Odontocetes), significant correlations were found between baleen whales (i.e. Mysticetes) and annual primary productivity ( $r=0.82$; $P<0.05$; Fig. 4), and between toothed whales (i.e. Odontocetes), including dolphins, and annual primary production ( $r=0.95 ; P<0.0001$; Fig. 5 ). This might be explained because of the different trophic levels for each species and different values of primary productivity for each marine habitat. This also suggests that the longer the marine food chain, the lower the amount of carbon and energy fixed in higher top trophic levels (i.e. O. orca). Using equation (3), the daily intake ranges from $2 \mathrm{fw}$ $\mathrm{km}^{-2} \mathrm{~d}^{-1}$ for killer whales to $688 \mathrm{fw} \mathrm{km} \mathrm{kd}^{-2}$ for bottlenose dolphins (Table 1). Galapagos sperm whales have a daily food intake of approximately $13 \mathrm{~kg} \mathrm{fw} \mathrm{km}^{-2} \mathrm{~d}^{-1}$, whereas the Bryde's whales have a daily food intake of $75 \mathrm{~kg} \mathrm{fw}$ $\mathrm{km}^{-2} \mathrm{~d}^{-1}$. These outcomes indicate that abundant cetaceans in Galapagos water, including both small cetaceans (i.e. T. truncatus) and baleen whales (i.e. B. edeni), are the organisms consuming more resources.

Calculating the sinking rate per day of beaks conforming part of the digested organic matter released by sperm whales, as reported by Smith (1992), the average sinking rates for small beaks is $3 \times 10^{3} \mathrm{~m} \mathrm{~d}^{-1}$, and the sinking rate for the largest beaks is $4.3 \times 10^{3} \mathrm{~m} \mathrm{~d}^{-1}$, which might indicate that large beaks defecated by sperm whales reach the bottom in an ocean of average depth $(=3800 \mathrm{~m})$ in less than one day ( $\sim .88 \mathrm{~d})$, and small beaks reach it in $1.29 \mathrm{~d}$. Larger beaks tend to sink faster because of their lower surface to volume ratio (Smith \& Whitehead 2000). The maximum sinking rate found for salps $\left(2,700 \mathrm{~m} \mathrm{~d}^{-1}\right)$ (Bruland \& Silver 1981) are relatively similar to the average sinking rate of small squid beaks, as well as to the minimum sinking rate of sperm whale fecal matter. This last scenario could be explained in account of the volume in small beaks. Volume and mass of sperm whales fecal matter haven not yet been determined (Dr. Hal Whitehead, pers. comm. ${ }^{2}$ ).

\section{Discussion}

This study was innovative in the sense that an effort to estimate cetacean production was conducted by relying on data regarding primary productivity, trophic levels and abundances of cetaceans. One of the major limitations rely on the scarcity of research concerning foraging and diet studies, trophic positions and population density of marine mammals around the Galapagos. However, data on mean abundances estimated from field observations

${ }^{2} 2002$. Department of Biology, Dalhousie University, Halifax, Nova Scotia, Canada. and expeditions around the Galapagos reported elsewhere (Merlen 1995, 1999, Palacios \& Salazar 2002, Palacios 2003) was used as the sample mean in this study. Very little is known on diet items or preys of Galapagos cetaceans, thus published data of a few species was collected (Merlen 1999, Smith \& Whitehead 2002, Flinn et al. 2002). Conversely, when information on preys or trophic levels was not available, the data from Pauly et al. (1998) was used. The lack of an adjusted daily intake equation for baleen whales feeding and correction factors for seasonal foraging behavior (i.e. cetaceans that not feed year round around Galapagos) were limiting aspects that were not accounted in the analysis.

One of the major strengths was the use of primary production data, as input in the calculations, retrieved from several studies and oceanographic expeditions recently conducted around waters of the Galapagos Islands and the tropical southeastern Pacific, as documented elsewhere (Torres \& Tapia 2002, Braun et al. 2005, Pennington et al. 2006). Most of the data has been documented by using values of chlorophyll $a$ (Torres \& Tapia 2002, Braun et al. 2005). However, estimates of annual primary production in units of grams of Carbon per square meter per year $\left(\mathrm{gC} \mathrm{m}^{-2} \mathrm{yr}^{-1}\right)$, used for estimations of tertiary production, are scarce. Barber \& Chavez (1991) reported a primary productivity mean value of 1096 milligrams of Carbon per square meter per day (mgC m-2 $\mathrm{yr}^{-1}$ ) for a zonal region of the Galapagos around the $90^{\circ}-93^{\circ} \mathrm{W}$, but estimates in an annual basis was not available. More recently, using the Vertical Generalized Productivity (VGP) model a more reliable estimate of $979 \mathrm{gC} \mathrm{m}^{-2} \mathrm{yr}^{-1}$ for euphotic zone (0-100m) of the Galapagos has been provided (Pennington et al. 2006). Ship-collected chlorophyll for the surface (0-5m) and euphotic zone were 0.65 and $42 \mathrm{mg} \mathrm{m}^{-3}$, respectively (Pennington et al. 2006).

An important aspect was also the consideration of the population ecology and natural history of each cetacean species recorded in the Galapagos and used in this study. In this study, a major assumption was stated regarding the fact of regular oceanographic conditions, indicating that the negative effects or impacts of natural phenomena such as the El Niño or La Niña were neglected. Future studies should emphasize the inclusion of these natural phenomena when estimating tertiary production.

Cetaceans are key components of marine trophic chains and carbon fluxes since, depending on the species, they are large and relatively abundant consumers influencing marine communities and, therefore, the functioning of marine food webs (Bowen 1997, Estes et al. 1998). In the Galapagos, sperm whales are the largest 
and probably the most important predator of deep-water cephalopods (Smith \& Whitehead 2000). Thus, fecal matter released from marine mammals such as sperm whales can also be reincorporated to the organic carbon like particle organic carbon (POC) to the web food through the vertical transport flux of organic matter. This ecological process is mainly occurring in upwelling areas (e.g. Galapagos Islands; Figs. 2-3) where the abundance of plankton and biodiversity of marine mammals is higher than in other tropical oceanic areas. However, the recent depletion of sperm whales around Galapagos waters might have critical consequences to the carbon flux pump and productivity in this insular region. A population number (females and immatures) below 500 animals was estimated to occur during the late 1990s, suggesting a significant reduction of the Galapagos population. Interestingly, while females and immatures were declining, the sighting rate for adult males augmented for the same period of time (Whitehead 2003). These observations suggested that females and immatures were probably moving out to previous feeding grounds along the continental shelf (Ecuador-Peru-Chile), where the regional stock of sperm whales were depleted during the whaling period (i.e. Peru), and adults males were exploiting unused resources/habitats (i.e. Galapagos waters) to overcome intraspecific competition by females (Whitehead 2003). Recently, a pod of 11 individuals was observed western Isabela Island on March 2008, suggesting that sperm whales are probably recovering and returning to their previous grounds in the Galapagos (J.J. Alava, pers. obs.).

It has also been suggested that sperm whales may aid nutrient cycling in the ocean by feeding at depth and defecating at the surface (Clarke 1997 in Whitehead 2003). According to Katona \& Whitehead (1988), sperm whales feces can provide at least $8 \%$ of the nitrogen used in primary production in a steady state, with no net horizontal transfer of nutrients, and they also could prolong a transient phytoplankton bloom, or induce a secondary, smaller bloom, following a major phase of production (Fig. 5). Large cetaceans may continue to play a major contribution even after death through the downward transfer of nutrients to benthic communities (Katona \& Whitehead 1988). This is supported due to the fact that large cetacean carcasses may be a major mechanism for dispersing deep-sea chemosynthetic communities on large areas (Smith et al. 1989). Rich productive and upwelling zones are found at the west and southwest of Galapagos Island, where sperm, Bryde's, blue and killer whales have been observed and studied (Merlen 1995, 1999), indicating viable oceanographic conditions for primary production as well as tertiary (e.g. blue, sperm and killer whales). At this level, Bryde's whales can be used as good indicators of tertiary production since these whales feed year round and are fairly common in Galapagos waters. This allows the estimation of a maximum daily intake in feeding areas.

The considerable tertiary production yielded in upwelling regions by baleen whales may be related to their oceanic distribution. Blue whales avoid the oligotrophic central gyres of the Pacific Ocean, but are more frequent where phytoplankton densities are high, and where there are dynamic oceanographic processes like upwelling and frontal meandering (Branch et al. 2007). Blue whales were observed feeding on surface swarms of Nyctiphanes simplex (euphausiid), and defecation was commonly seen (Palacios 1999b). This confirms that this baleen species forages in zooplankton available in Galapagos waters.

Moreover, marine mammals are mainly concentrated at the west part of the Galapagos Marine Reserve (Alava 2002, Palacios 2003). At the Equatorial upwelling region the chlorophyll concentration in the euphotic zone can reach a value of $42 \mathrm{mg} \mathrm{m}^{-3}$ (Pennington et al. 2006). This supports the fact that the Galapagos Islands are a sanctuary for whales because of the diversity of coastal and oceanic habitats prompting the utilization of this marine region as part of the home range, feeding, mating and breeding grounds. The quality of these marine habitats (i.e, supply of food and refuge), therefore, enhances survival, genetic flow and animal fitness.

Although humpback whales are abundant in coastal waters off Ecuador from June to September, they were not included for the estimations in tropical waters of the Galapagos because is a rare species that come here generally to breed (Merlen 1995, Alava 2002, Clarke et al. 2002). However, humpbacks might occasionally feed in upwelling zones. Humpback whale feeding on fish schools has been observed by experienced artisanal fishermen near the Island of La Plata (1 ${ }^{\circ} 23^{\prime} \mathrm{S}-80^{\circ} 58^{\prime} \mathrm{W}$; Machalilla National Park, Ecuador) where the whales might be predating on anchovies (Anchoa spp.) (Alava $2001^{3}$ ), or other species of school/forage fish such as thread herrings (Opisthonema sp.) and sardines (Sardinops sagax). Despite reduced feeding rates have been documented for large baleen whales in tropical/ breeding areas or warm waters, where energy budgets are mainly allocated in mating and calving (Lockyer 1981), observing feeding behavior of humpbacks in these areas

\footnotetext{
${ }^{3}$ Alava, JJ. 2001. Capacitación sobre la ballena jorobada y delfines al sector pesquero artesanal. Informe técnico presentado a la Subsecretaría de Recursos Pesqueros (SRP)MICIP (unpublished). II Anexos, 4 pp.
} 
is a more frequent event than previously thought, as reported elsewhere (Baraff et al. 1991, Gendron \& Urban 1993, Alava 2001). Thus, it cannot be ruled out that at least occasionally, humpbacks may feed on anchovy schools.

Bottlenose dolphins are excellent models to use to explain the efficiency of energy and secondary production in coastal regions because they are frequently common in estuarine areas. According to Pauly et al. (1998), bottlenose dolphins have a trophic level of 4.2, and they predate both on small pelagic fishes and on demersal fishes. Recently, Young \& Phillips (2002) estimated the proportion of annual primary production demanded to support bottlenose dolphins within the $32 \mathrm{~km}^{2}$ North Inlet salt marsh creek system in South Carolina, USA. They determined that a range of $3.2 \%-6.8 \%$ of the total annual primary production of this system is needed to maintain an average population of only six dolphins, which can consume 1.60-2.10 x 10 $\mathrm{gC} \mathrm{yr}^{-1}$ or 11.1-14.2 ton of fish (wet weight) each year in North Inlet. For example, applying and assuming the same minimum estimation of this biomass consuming to the minimum confidence interval value of coastal bottlenose dolphin population of the Guayaquil Gulf Estuary, where there are about 500 individuals (Felix 1994), they would consume approximately $133 \times 10^{6} \mathrm{gC} \mathrm{yr}^{-1}$ or 925 ton of fish (drums and anchovies) each year in that region. Therefore, bottlenose dolphins have a significant ecological impact and can be important predators (Young \& Phillips 2002). Applying the same rationale to $50 \%$ of the bottlenose dolphin's abundance estimated for the Galapagos $(\approx 6000$ individuals, Table 1), a minimum of $1.6 \times 10^{9} \mathrm{gC} \mathrm{yr}^{-1}$ or 11,100 ton of fish is required to sustain half of this population abundance. Since no studies on preys or fish species part of the bottlenose dolphin's diet are available for the Galapagos, it is difficult to know what species are commercially important (e.g. mullets, Mugil spp.) for local fisheries. On the other hand, is too premature to extrapolate the proportion of or competition for fisheries that bottlenose dolphins are accounting for.

The apex cetacean predator in the marine ecological pyramid of the GMR is the killer whale (Orcinus orca). Its low population abundance and value of tertiary production supports this argument (Tables 1 and 2). In nature, top predators are generally in small numbers in both terrestrial and marine ecosystems. Sea lion predation by killer whales, including breaching on seashore by an orca attacking a sea lion, has been recorded for the Galapagos (see Merlen 1999). Likewise, killer whales attacks and predation on baleen whales, including Bryde's whale, has been evidenced at sea (Merlen 1999, Ben Haase, pers. comm. ${ }^{4}$ ) This suggests that killer whales in the Galapagos may also have a similar ecology to the marine-mammal eating 'transient' and 'offshore' killer whale ecotypes known from the cold temperate waters of the eastern North Pacific (Ford et al. 2001). The killer whale might share its trophic position with another top carnivorous predator potentially present in the Galapagos, the great white shark (Carcharodon carcharias), which also has the same trophic level (TL=4.5; Cortes 1999). However, it has been rarely recorded for Galapagos marine waters (Grove et al. 1984). Killer whales may also occasionally eat great white sharks, as a possible case of competitive displacement (Pyle et al. 1999) or intraguild predation. However, presence of great whites in Galapagos waters is anecdotal, and may be restricted to juveniles, preferring to eat the less abundant Galapagos fur seals because of their greater fat content instead of sea lions, which might partially explains their general absence in the GMR.

The effect of consumption on local fisheries by marine mammals in the Galapagos is unknown, although the amount of prey consumed by Pacific marine mammals, which represent a total biomass of approximately 25 million ton, was reported at about 150 million ton of food per year (Trites et al. 1997). Meanwhile, around the GMR, the potential effects of removing shark species due to overfishing or illegal fishing (i.e. shark finning) on marine mammals, mainly toothed cetaceans such as killer whales that predate on sharks, is still unknown. Similarly, the bycatch (i.e. long-line fishing) denotes an immediate impact to marine animals, jeopardizing the survival of not only resident marine mammals (cetaceans and Galapagos otariids), but sharks, sea turtles and sea birds. Moreover, it is poorly understood what could be the cascade effect on marine mammal populations by extirpating Galapagos keystone species, including sea cucumbers (Isostichopus fuscus), red lobsters (Panulirus penicillatus) and white sea urchins (Tripneustes depressus), from the bottom-up control process, as well as sharks on the top-down process within the marine food chain of GMR (Fig. 1).

Recent modeling work using Ecopath and Ecosim approaches on sea cucumber exploitation in the Galapagos has also shown that catch rates of this species are unsustainable and even with a level of $23 \%$ of protection in a hypothetical non-extractive zone from fishing, a 23\% decline of the total sea cucumber biomass is predicted (Okey et al. 2004). Similarly, the removal of herbivorous fish such as surgeonfish, parrotfish and damselfish by

${ }^{4}$ 2008. Fundación Ecuatoriana para el Estudio de Mamíferos Marinos (FEMM)/Museo de Ballenas, Salinas, Península de Santa Elena, Ecuador. 
potential overfishing could cause reduction of species abundance in the upper two trophic levels and increasing of algae (i.e. brown, green and red seaweed and algal turf) (Branch et al. 2002). If secondary or tertiary production becomes unbalanced, and there is a decrease in consumers at some trophic levels, top predators may shift their diets preferences and take a different suite of prey species, causing changes in carbon flux and food chains in particularly sensitive areas of Galapagos. This might cause drastic effect in the bottom up processes of the Galapagos marine food web affecting local marine mammals.

\section{Acknowledgments}

The author thanks Dr. Robert Feller, professor of Advanced Biological Oceanography, University of South Carolina, for encouraging me to write this manuscript in 2002. The author also thanks Dr. John Kucklick and Dr. Claude Joiris for the valuable suggestions to improve an early draft of this article, as well as Dr. Stuart Banks and the reviewers for their productive insights and comments to the last version of this contribution.

\section{Literature cited}

Alava JJ. 2002. Registros y abundancia relativa de mamíferos marinos durante el crucero oceanográfico insular B/I ORION (CO-II-2000) en las Islas Galápagos y sus alrededores. Acta Oceanográfica del Pacífico 11: 165-172.

Baraff LS, PJ Clapham, DK Mattila \& RS Bowman. 1991. Feeding behavior of humpback whales in low latitude waters. Marine Mammal Science 7: 197-202.

Barber RT \& FP Chavez. 1991. Regulation of primary productivity rate in the equatorial Pacific. Limnology and Oceanography 36: 1803-1815.

Bowen WD. 1997. Role of marine mammals in aquatic ecosystems. Marine Ecology Progress Series 158: 267-274.

Branch GM, JD Witman, R Bensted-Smith, RH Bustamante, GM Wellington, F Smith \& GJ Edgar. 2002. Conservation criteria for the marine biome. In: Bensted-Smith R (ed). A Biodiversity vision for the Galapagos Islands, pp. 72-79 Charles Darwin Foundation/World Wildlife Fund, Puerto Ayora, Galapagos Island.

Branch TA, K Matsuoka \& T Miyashita. 2004. Evidence for increases in Antarctic blue whales based on Bayesian modelling. Marine Mammal Science 20: 726-754.

Branch TA, KM Stafford, DM Palacios, C Allison, JL Bannister, CLK Burton, E Cabrera, CA Carlson, B Galletti-Vernazzani, PC Gill, R Hucke-Gaete, K Jenner, M Jenner, K Matsuoka, YA Mikhalev, T Miyashita, M Morrice, S Nishiwaki, VJ Sturrock, D Tormosov, RC Anderson, AN Baker, PB Best, P Borsa, RL Brownell Jr, S Childerhouse, KP Findlay, T Gerrodette, AD Ilangakoon, M Joergensen, B Kahn, DK Ljungblad, B Maughan, RD McCauley, S Mckay, TF Norris, S Rankin,
F Samaran, D Thiele, K van Waerebeek \& RM Warneke. 2007. Past and present distribution, densities and movements of blue whales Balaenoptera musculus in the Southern Hemisphere and Northern Indian Ocean. Mammal Review 37: 116-175.

Braun M, J Ortiz, E Pinto, T de la Cuadra, E Zambrano, R Flores, C Grados, L Pizarro \& U Munaylla. 2005. Meteorological and oceanographic conditions in the Southeast Pacific during September - October 2004. CPPS Seventh regional joint oceanographic research cruise in the South East Pacific (September-October 2004), Guayaquil. Final Report, pp. 19-25.

Bruland KW \& MW Silver. 1981. Sinking rates of fecal pellets from gelatinous zooplankton (Salps, Pteropods, Doliolids). Marine Biology 63: 295-300.

Clarke R, F Félix, O Paliza \& P Britnik. 2002. Ballenas y delfines observados por la expedición Ballenas Libres durante el crucero oceanográfico CO-II-01 entre Guayaquil y las Islas Galápagos del 17 de septiembre al 9 de octubre de 2001. Acta Oceanográfica del Pacífico 11: 173-180.

Cortes E. 1999. Standardized diet compositions and trophic levels of sharks. ICES Journal of Marine Science 56: 707-717.

Estes JA, MT Tinker, TM Williams \& DF Doak. 1998. Killer whale predation on sea otters linking oceanic and nearshore ecosystems. Science 282: 473-476.

Félix F. 1994. Ecology of the coastal bottlenose dolphin Tursiops truncatus in the Gulf of Guayaquil, Ecuador. Investigations on Cetacea 25: 235-256.

Fertl D, A Acevedo-Gutierrez \& FL Darby. 1996. A report of killer whales (Orcinus orca) feeding on a carcharhinid shark in Costa Rica. Marine Mammal Science 12: 606-611.

Flinn RD, AW Trites, EJ Gregr \& I Perry. 2002. Diets of fin, sei and sperm whales in British Columbia: an analysis of commercial whaling records, 1963-1967. Marine Mammal Science 18: 663-679.

Ford JKB, GM Ellis \& KC Balcomb. 2000. Killer whales: the natural history and genealogy of Orcinus orca in British Columbia and Washington State, 104 pp. University of British Columbia Press, Vancouver.

Gendron D \& J Urban. 1993. Evidence of feeding by humpback whales (Megaptera novaeangliae) in the Baja California breeding ground, Mexico. Marine Mammal Science 9: 76-81.

Grove J, S Massay \& S Garcia. 1984. Peces de las Islas Galápagos, Ecuador. Boletín Científico y Técnico, Instituto Nacional de Pesca 7: 1-157.

Innes S, DM Lavigne, WM Earle \& KM Kovacs. 1987. Feeding rates of seals and whales. Journal of Animal Ecology 56: 115-130.

Jefferson TA, S Leatherwood \& MA Webber. 1993. Marine mammals of the world. FAO Species Identification Guide, 320 pp. FAO, Rome.

Joiris CR. 1992. Summer distribution and ecological role of seabirds and marine mammals in the Norwegian and Greenland seas (June 1998). Journal of Marine Systems 3: 73-89. 
Joiris CR. 2000. Summer at - sea distribution of seabirds and marine mammals in polar ecosystems: a comparison between the European Arctic seas and the Weddell Sea, Antarctica. Journal of Marine Systems 27: 267-276.

Joiris CR \& R Tahon. 1992. Distribution and food intake of seabird and marine mammals in the Norwegian and Greenland seas (July 1988). Proceedings of the symposium, Whales: Biology-Threaths-Conservations, Royal Academy of Overseas Sciences, Brussels, Belgium, pp. 113-133.

Katona S \& H Whitehead. 1988. Are cetacea ecologically important?. Oceanography and Marine Biology: An Annual Review 26: 553-568.

Lalli CM \& TR Parson. 1997. Biological oceanography: an introduction, 314 pp., Butterworth-Heinemonn, Vancouver.

Laws RM. 1984. The ecology of the Southern Ocean. American Scientist 73: 26-40.

Legendre L \& RB Rivkin. 2002. Fluxes of carbon in the upper ocean: regulation by food-web control nodes. Marine Ecology Progress Series 242: 95-109.

Lockyer C. 1981. Growth and energy budgets of large baleen whales from the Southern Hemisphere. In: Gordon J (ed). Mammals in the seas. Vol. III. General Papers and Large Cetaceans FAO Fisheries Series 5: 379-487.

Merlen G. 1995. A field guide to the marine mammals of the Galapagos, 130 pp. Instituto Nacional de Pesca, Guayaquil.

Merlen G. 1999. The orca in Galapagos: 135 sightings. Noticias de Galápagos (Galápagos News) 60: 2-8.

Okey TA, S Banks, AF Born, R Bustamante, M Calvopiña, G Edgar, E Espinoza, JM Fariña, V Francisco, LE Garske, S Salazar, S Shepherd, V Toral \& P Wallem. 2004. A balanced trophic model of a Galapagos subtidal rocky reef for evaluating marine conservation strategies. Ecological Modelling 172: 383-401.

Palacios DM. 1999a. Marine mammal research in the Galápagos Islands: The 1993-1994 Odyssey Expedition. Final Report, 46 pp. Galapagos National Park Service and Charles Darwin Research Station, Puerta Ayora, Islas Galápagos.

Palacios DM. 1999b. Blue whale (Balaenoptera muculus) occurrence off Galapagos Islands, 1978-1995. Journal of Cetacean Research and Management 1: 41-51.

Palacios DM. 2003. Oceanographic conditions around the Galapagos Archipelago and their influence on cetacean community structure. Ph. D. Thesis, Oregon State University, Corvallis, Oregon, 178 pp.

Palacios DM \& S Salazar. 2002. Cetáceos. In: Danulat E \& GJ Edgar (eds). Reserva marina de Galápagos, línea base de la biodiversidad, pp. 291-304. Fundación Charles Darwin/Servicio Parque Nacional Galápagos, Santa Cruz, Galápagos.
Pauly D \& V Christensen. 1995. Primary production required to sustain global fisheries. Nature 374: 255-257.

Pauly D, AW Trites, E Capuli \& V Christensen. 1998. Diet composition and trophic levels of marine mammals. ICES Journal of Marine Science 55: 467-481.

Pennington JT, KL Mahoney, VS Kuwahara, DD Kolber, $R$ Calienes \& FP Chavez. 2006. Primary production in the eastern tropical Pacific: A review. Progress in Oceanography 69: 285-317.

Pyle P, MJ Schramm, C Keiper \& SD Anderson. 1999. Predation on a white shark (Carcharodon carcharias) by a killer whale (Orcinus orca) and a possible case of competitive displacement. Marine Mammal Science 15: 563-567.

Small LF, SW Fowler \& MY Unlu. 1979. Sinking rates of natural copepod fecal pellets. Marine Biology 51: 233-241.

Smith CR, H Kukert, RA Wheatcroft, PA Jumars \& JW Deming.1989. Vent fauna on whale remains. Nature 341:27-28

Smith SC. 1992. Sperm whales and mesopelagic cephalopods in the waters off the Galápagos Islands. MSc. Thesis, Dalhousie University, Nova Scotia, 66 pp.

Smith SC \& H Whitehead. 2000. The diet of Galápagos sperm whales Physeter macrocephalus as indicated by fecal sample analysis. Marine Mammal Science 16: 315-325.

Sorisio LS, A de Maddalena \& IN Visser. 2006. Interactions between killer whales and hammerhead sharks in Galapagos waters. Latin American Journal of Aquatic Mammals 5: 69-71.

Springer AM, JF Piatt, VP Shuntov, GB van Vliet, VL Vladimirov, AE Kuzin \& AS Perlov. 1999. Marine birds and mammals of the Pacific gyres. Progress in Oceanography 43: 443-487.

Torres G \& ME Tapia. 2002. Fitoplancton en el afloramiento de las Islas Galápagos, durante agosto 2000. Acta Oceanográfica del Pacífico 11: 53-62.

Trites AW \& D Pauly. 1998. Estimating mean body masses of marine mammals from maximum body lengths. Canadian Journal of Zoology 76: 886-896.

Trites AW, V Christensen \& D Pauly. 1997. Competition between fisheries and marine mammals for prey and primary production in the Pacific Ocean. Journal of Northwest Atlantic Fishery Science 22: 173-187.

Whitehead H. 2002. Estimates of the current global population size and historical trajectory for sperm whales. Marine Ecology Progress Series 242: 295-304.

Whitehead H. 2003. Sperm whales: social evolution in the ocean, 431 pp. University of Chicago Press, Chicago.

Young RF \& HD Phillips. 2002. Primary production required to support bottlenose dolphins in a salt marsh estuarine creek system. Marine Mammal Science 18: 358-373. 